\title{
9 Law-making activity of the Polish Constitutional Tribunal
}

\author{
Piotr Czarny and Bogumit Nalezinski
}

The Polish Constitutional Tribunal (CT) is the oldest judicial review body for the constitutionality of laws in the post-communist countries of Central and Eastern Europe. It was established in 1986, even before the political transformations of 1989 to 1990. It was founded with the intention of it being the fundamental guarantor of the superiority of the Constitution in the system of sources of law. The legal solutions that define its organization and powers are based on the model of a concentrated review of the constitutionality of laws, whose foundations were laid down by $\mathrm{H}$. Kelsen. The constitutional provisions currently in force in Poland can be treated as a partial adoption of the Austrian and German regulations, supplemented with some important additional elements.

The implementation of the most important function of any constitutional court - namely, guaranteeing that legislative bodies adhere to the Constitution means that such courts have a significant impact on the existing legal order. The CT's activity shows that this influence has at least some features that go beyond applying the law, and resemble - although to a limited extent - law-making.

The issue is highly complex. ${ }^{1}$ The research assumption that led to the reflections that follow in this chapter was the hypothesis that, in its activity, the CT creates norms, which in practice are treated as if they were part of the applicable law. This process is different at the level of constitutional norms and at the level of statutory (or lower ranking) norms.

\section{Establishment of the Constitutional Tribunal in Poland}

The establishment of the CT is linked to the amendments to the then-applicable Constitution, introduced by the Act of 26 March 1982 on Amendments to the 1952 Constitution. $^{2}$ For the CT to actually be set up, an ordinary statute had to be drafted and then adopted. In view of the highly general formulation of constitutional norms, this was a necessary prerequisite for its

1 Marcin Dąbrowski, Funkcje Trybunatu Konstytucyjnego zwiąane z hierarchiczna kontrola konstytucyjności prawa (Wydawnictwo Uniwersytetu Warmińsko-Mazurskiego 2015) 102-103.

2 Polish official journal Dziennik Ustaw (DzU) no 11, item 83.

DOI: $10.4324 / 9781003022442-10$ 
establishment. ${ }^{3}$ The Act was passed much later, in April 1985, and it entered into force on 1 January 1986; thus, this later date is viewed as the start of the Polish CT, which issued its first ruling on 28 May 1986.

In accordance with Article 33a inserted into the 1952 Constitution, the CT was established as an authority for the concentrated review of laws, but its decisions had a rather limited impact. This was a consequence of the solution that required CT decisions concerning the unconstitutionality of statutes to be approved by the Sejm to take full effect. Thus, this solution formally gave the parliament the final say, and in the broader political context, it enabled reconciliation of the review powers of the CT with the constitutionally guaranteed superior position of the Sejm over all other State authorities. From the organizational point of view, the 1952 Constitution also provided for the election of CT judges by the Sejm, and for their special status resulting from the principle of independence and subordination only to the Constitution.

Taking into account the timeline of the above events, it is apparent that the CT was created in the political reality of the so-called socialist democracy, in a system governed by the principles of the unity of State power (in terms of the legal aspect) and the hegemonic role of the ruling political party (in terms of the political aspect). This specific normative environment of the CT gradually evolved as the law was amended in the 1990s. ${ }^{4}$ Its final stage was the adoption and entry into force of the current Constitution of the Republic of Poland of 2 April 1997.

\section{Legal basis, systemic position, and powers of the Constitutional Tribunal}

The currently functioning CT has its constitutional anchor in numerous and more detailed provisions of the 1997 Constitution. ${ }^{5}$ These include, first of all, Article 10 (2) of the Constitution, according to which the CT belongs - together with the Tribunal of the State (TS) - to a separate segment of the judicial power, and with a separate part of Chapter VIII of the Constitution (Articles 188-197) being devoted specifically to the CT. Two general provisions in this chapter that relate equivalently to all judicial authorities (Articles 173-174) also apply to the CT. The constitutional regulations concerning the CT's functioning also include provisions contained in other parts of the 1997 Constitution. Outside Chapter VIII, one can find regulations on the constitutional complaint procedures, as well as on the powers of the President of the Republic and the National Council of the Judiciary, to submit such applications to the CT.

3 Act of 29 April 1985 on the Constitutional Tribunal (DzU no 22, item 98, as amended).

4 These changes resulted, among other things, in an extension of the original scope of powers of the CT to include the universally applicable interpretation of statutes and the review of the constitutionality of the objectives and activities of political parties.

5 Constitution of the Republic of Poland of 2 April 1997 (DzU no 78, item 483, as amended). 
The delegation in Article 197 of the Constitution for the legislator to regulate the issue of the organization of the CT and procedures before the CT was initially implemented by the adoption of the Act of 1 August 1997 on the Constitutional Tribunal. ${ }^{6}$ This legal act remained in force for almost eighteen years with hardly any amendments. One of the effects of the constitutional crisis that occurred after the presidential and parliamentary elections in 2015 was major amendments to the statutory regulation of the CT. ${ }^{7}$ Nowadays the delegation contained in Article 197 of the Constitution is implemented by two statutes concerning, respectively, the organization of the CT and the procedure it follows, ${ }^{8}$ and the status of CT judges. ${ }^{9}$

Determining the CT's position in the system of government established by the 1997 Constitution seems to be much easier than under the regulations in force in the 1980s when the CT was created. This results first of all from the unambiguous wording of Article 10(1) and (2) of the Constitution, which expressly classify the CT as an authority of the judicial power, while making it (together with the TS) part of a separate segment of that power (in relation to courts). This systemic classification is, to a large extent, consistently taken into account in the further systematics of the constitutional provisions. Consequently, matters relating to the CT are regulated (as a rule) in Chapter VIII of the Constitution, entitled 'Courts and Tribunals,' firstly under the heading, 'the Constitutional Tribunal'.

The fact that the Constitution-maker gave the CT the status of a 'third power' authority has significant consequences, due to the requirement to respect the CT's separate nature and independence from other branches of power (Article 173), while including it fully in the structure of a democratic rule-of-law state (Article 2) on whose behalf the CT is to issue its judgements (Article 174).

The actual normative formulation of the principles indicated in Article 173 of the Constitution is directly affected by the content of other provisions of the Constitution relating to the CT. On the one hand, they deprive the principles of 'separateness' and 'independence' of their absolute nature and, on the other hand, they are intended to serve as directives restricting the freedom of interpretation of those provisions in a direction that is incompatible with the requirement of guaranteeing the CT the status enjoyed by judicial authorities. Regardless of this, the principles expressed in Article 173 must be fully implemented by the statutory provisions where the constitutional delegation is clarified to determine the details of the CT's organization and the procedures that it follows.

6 DzU no 102, item 643, as amended.

7 They resulted in the adoption of subsequent Acts on the Constitutional Tribunal, as well as numerous amendments to these statutes, see Piotr Radziewicz \& Piotr Tuleja (eds.), Konstytucyjny spór o granice zmian organizacji $i$ zasad dziatania Trybunatu Konstytucyjnego; czerwiec 2015 - marzec 2016 (Wolters Kluwer 2017).

8 Act of 30 November 2016 on the Organization of the Constitutional Tribunal and the Mode of Proceedings Before the Constitutional Tribunal (DzU, item 2072), further, as the Act on the CT's Organization.

9 Act of 30 November 2016 on the Status of the Judges of the Constitutional Tribunal (DzU 2018, item 1422). 
Undoubtedly, the very mechanism of appointing the fifteen CT judges (who are elected individually by the Sejm for a nine-year term) is the exemption from the principle of the separateness and independence of the CT from the other branches of power. ${ }^{10}$ Additionally, the aforementioned authorization for the parliament to regulate the matters referred to in Article 197 of the Constitution must be seen as a restriction upon the full - organizational and functional - independence of the CT. The political link between the CT and the executive power is a consequence of the fact that the President of the Republic of Poland is granted the power to appoint the CT president and vice-president from among the candidates presented by the General Assembly of CT judges. ${ }^{11}$ However, the CT's separateness and independence also concerns its relations with other judicial authorities, including the courts - the Supreme Court (SC) and Supreme Administrative Court (SAC) and the TS.

The current constitutional regulations also include solutions that undoubtedly strengthen - also in comparison to other judicial authorities - the principles enshrined in Article 173. These include, in particular, guaranteeing CT judges a special legal status resulting from the principle of their subordination only to the Constitution, as well as making the CT's judgements final and universally binding - Article 190(1).

Not only does the CT's separation from the 'court' segment of the third power have significant consequences in terms of a lack of any 'judicial' subordination of the CT to the highest courts (i.e. the SC and SAC), but it also excludes the CT from the scope of application of general systemic solutions (organizational and functional) relating to courts adjudicating in the Republic of Poland. These include, among others, the principle of at least two instances of court proceedings, the presumption that the court has jurisdiction, and the principle of the participation of citizens in the administration of justice. However, there is no doubt that the principle of independence and the accompanying constitutional guarantees (judges being apolitical, their immunity, and freedom from detention) are common to all the bodies of the judicature, in particular, to the judges adjudicating in these bodies. In contrast to the very general and laconic constitutional basis of the CT's activity in the period before 1997, the provisions of the current Constitution set out a detailed and exhaustive list of CT functions, as well as the most important powers vested in the CT for it to perform those functions.

Apart from the organizational sphere, the distinctness and independence of the CT as a judicial authority can be seen in the functions performed by that authority. It should be emphasized that in light of the current Constitution, the following functions may be assigned to the CT: reviewing the constitutionality and legality of laws (Article $188(1)$ to $(3)$ ); adjudicating in matters of constitutional

10 It is a type of continuation of the solution resulting from Article 33a of the 1952 Constitution that the authors of the current Constitution limited themselves to indicating in it only one necessary condition: that candidates for judges of the Tribunal be 'persons distinguished by their knowledge of the law'.

11 Pursuant to Article 144(3)(21) of the 1997 Constitution, the official act of appointment does not require the Prime Minister's signature for its validity. 
complaints (Article 79 and Article 188(5)); resolving competence disputes (Article 189); reviewing the constitutionality of aims or activities of political parties (Article 188(4)); and deciding whether the President of the Republic is unable to (temporarily) hold office (Article 13l(1)). The first two of the aforementioned functions are of a similar quality, because, due to the constitutional complaint model adopted by the Polish Constitution-maker, the CT's examination of this legal remedy actually also means that the CT reviews the constitutionality of laws. Compared to the laws in force before 1997, the list of CT functions was thus extended, on the one hand, but on the other hand, it was significantly limited - especially in terms of the issues discussed in this book - when the CT was deprived of its power to determine the universally binding interpretation of statutes. ${ }^{12}$

However, the actual role that a public authority plays in a state's system of government is determined not only by the content of the legal norms that form the basis of its organization and functioning, but also by how the norms are applied by the addressees. Even though the Constitution-maker intended the CT to be an element of an independent judiciary, it is exposed to particular threats, which may undermine its (assumed) apolitical status in both its personal and functional aspects. This adverse phenomenon, resulting from the way in which some of the CT's judges were elected, from the procedure it follows, and from the content of its decisions, has been observed in Poland since the 2015 parliamentary election. Its consequences have included denying the constitutional mechanisms of checks and balances, as well as undermining confidence in the CT both among legal scholars and numerous civil society groups.

\section{The degree of public confidence in the Constitutional Tribunal and the degree of public acceptance of its judgements}

The position of the CT is affected not only by its formal position, but also by the social context in which it operates. When it comes to public trust in the CT, it must be noted that generally, Poles display an overall low level of trust. According to a poll conducted in 2018 by the CBOS, ${ }^{13}$ only about $20 \%$ of Poles believe that most people can be trusted. ${ }^{14}$ From among all the public institutions, local selfgovernment authorities enjoy the highest levels of trust: almost two-thirds of adult Poles declared they trusted them. ${ }^{15}$ According to the aforementioned poll, half of the respondents did not trust the CT, with just $25 \%$ declaring their trust. The

12 Moreover, as per Article 239(3) of the Constitution, such interpretive resolutions adopted by the Tribunal before the Constitution entered into force lost their universally binding force.

13 The Centrum Badania Opinii Społecznej (Public Opinion Research Centre) is a state foundation whose task is, among others, to collect, process and share data from social opinion polls; it is supervised by the Prime Minister, who appoints the majority of members of the CBOS Board; hence, its full objectivity is sometimes questioned.

14 CBOS, O nieufności i zaufaniu, CBOS poll report no 35/2018, l (11 July 2019) www.cbos.pl/SPISKOM.POL/2018/K_035_18.PDF.

15 Ibid., 7. 
results for courts were similar in terms of the level of mistrust, but the level of trust was higher (33\%). Additionally, it should be noted that slightly more than half of the respondents had no trust in the legislative power; that is, the parliament $(53 \%$, with $34 \%$ expressing trust). ${ }^{16}$

In an earlier CBOS poll in $2016,37 \%$ of respondents trusted the CT, while $36 \%$ did not. ${ }^{17}$ It is plain to see that a change in public attitude to the CT took place. The credibility of the CT in the eyes of the public declined most sharply compared to other public authorities: trust in it fell by as much as thirteen percentage points, while distrust rose by fourteen points.

As for the attitude towards the activity of the CT, from 2002 to 2015 , the share of negative assessments was slightly above $10 \%$, while positive assessments ranged from $40 \%$ to $60 \%$. Since the autumn of 2015 , there has been a strong upwards trend in negative assessments (to approximately $45 \%$ in the spring of 2017) and, understandably, a downwards trend in positive assessments (to an all-time low of $20 \%$ in March 2017). ${ }^{18}$ The data from March 2019 shows a gradual improvement in opinions about the CT's activity, although there is still more criticism (34\%) than approval $(30 \%)$.

In general, it can be concluded that in comparison to other constitutional courts, both the level of public trust in the CT and the public assessment of its activities are rather low. This level further decreased significantly from 2015 to 2017, which was undoubtedly one of the effects of the constitutional crisis in Poland.

\section{Manifestations of law-making in the Constitutional Tribunal's activity}

The current provisions of the aforementioned statutes, which regulate the CT's activity, authorize it to issue normative acts; that is, to make laws. This includes the adoption of the Tribunal's Rules of Procedure, the Statutes of the Tribunal's Chancellery, and the Statutes of the Legal Service Office, as well as the Code of Ethics of Judges of the Constitutional Tribunal. ${ }^{19}$ The subject matter of the Tribunal's Rules of Procedure is defined in a fairly detailed way. It mainly determines the rules of the internal organization of the work of the General Assembly and the CT's president. The power to lay down the rules of procedure does not imply that the CT has been granted procedural autonomy, since, in matters not regulated by that statute, the provisions of the Code of Civil Procedure apply mutatis mutandis to proceedings before the $\mathrm{CT}{ }^{20}$

16 Ibid.

17 CBOS, Zaufanie społeczne, CBOS poll report no 18/2016, 13-14 (9 July 2019), www.cbos.pl/SPISKOM.POL/2016/K_018_16.PDF.

18 CBOS, Oceny działalności instytucji publicznych, poll report no 44/2019, 5 (12 July 2019), www.cbos.pl/SPISKOM.POL/2019/K_044_19.PDF.

19 In administrative matters, the statute and the Rules of Procedure of the Constitutional Tribunal also confer some limited law-making powers on the president of the CT.

20 Article 36 of the Act on the CT's Organization. 
The Code of Ethics of Judges of the Constitutional Tribunal, which should define the standards of behaviour of judges, has a special nature. The Code does not consist of legal norms in the strict sense of the word, but their violation constitutes grounds for disciplinary action.

All the aforementioned legal regulations are adopted by the General Assembly of CT Judges. They may be regarded as sources of internal law and therefore their practical significance is limited. They must be compatible not only with the Constitution, but also with other universally binding legal acts (especially statutes).

In general, it can be said that the aforementioned power to make laws is incidental and marginal in the context of the CT's exercise of its constitutional powers.

The CT's activity that displays major features of law-making and that has a significant impact on the legal order takes place in its case law (decisions on specific cases). This statement is mainly justified through an analysis of the CT's practice, because the Constitution itself does not directly empower the CT to make laws, as it includes this in the judicial authorities whose task is to apply laws. Moreover, the Constitution follows a normative (positivist) concept of the sources of law, expressed primarily in Chapter III. CT judgements are not listed among the sources of law, therefore some Polish scholars even conclude that the Constitution prohibits judicial law-making. ${ }^{21}$ In addition, the CT itself stresses that the principle of the separation of powers excludes its participation in the exercise of the legislative power. ${ }^{22}$ However, CT judgements have one important feature in common with the sources of law in the formal sense of the word: their universally binding force. ${ }^{23}$

However, the issue is much more complicated than that. In Poland, since the 1960s, opinions have been expressed that general norms (legal principles) may emerge from case law and, even though they do not result directly from the provisions of laws, they may, in practice, function as if they were statutory norms. ${ }^{24}$ And as for the closed nature of the system of the sources of law in the 1997 Constitution, it has been pointed out that it is not absolute. This closed nature should mainly concern enactments, so one cannot exclude customary law or court precedents perhaps being treated as sources of law of a specific nature. ${ }^{25}$ Although the CT is not a court within the meaning of the constitutional provisions, its judicial law-making activity cannot be regarded as completely unacceptable.

The CT activity that can be treated as actual law-making can be seen, first and foremost, at the constitutional level. The CT is obliged to prepare, ex officio, a written statement of reasons for its judgement. ${ }^{26}$ In order for the statement of

21 See Dąbrowski (n 1), 262.

$22 \mathrm{~K} 11 / 06$, of 19 July 2007.

23 See Articles 87 and 190(1) of the Constitution.

24 Andrzej Stelmachowski, 'Prawotwórcza rola sądów (w świetle orzecznictwa cywilnego)’ (1967) 4-5 Państwo i Prawo 611, 612.

25 Roman Hauser \& Janusz Trzciński, Prawotwórcze znaczenie orzeczeń Trybunatu Konstytucyjnego w orzecznictwie Naczelnego Sadu Administracyjnego (LexisNexis 2008) 10-11.

26 Article 108(3) of the Act on the CT's Organization. 


\section{2}

reasons to be correct from the point of view of the legal methodology, and in terms of a convincing correct decision, the CT must compare (juxtapose) the contents of the reviewed legal norm and the constitutional norm that constitutes an adequate basis for a review.

The statement of reasons is important from the point of view of so-called substantive legitimacy. It assumes that 'the very process of making legal decisions, thanks to its rationality and fairness, becomes a substantive source of these decisions' legitimacy. ${ }^{27}$ An important feature of such a process is revealing the reasons for the decision in a clear manner, which matters from the point of view of avoiding arbitrariness.

The substance of constitutional norms should be determined through their interpretation by means of commonly accepted interpretation methods. Due to the highly abstract way some provisions of the Constitution are formulated, the process of establishing their meaning is, by definition, creative, very often involving their concretization; that is, the formulation of more detailed rules (norms). ${ }^{28}$ This phenomenon may, in a way, be illustrated with the issue of the substance of the principle of the separation of powers. ${ }^{29}$ One of the conclusions derived by the CT from this principle is that each of the three branches should have substantive powers corresponding to its essence and that each of them should retain certain minimum powers required to preserve this essence. ${ }^{30}$ Consequently, when examining an alleged violation of Article 10 of the Constitution, in which this principle of the separation of powers is expressed, the CT begins by checking whether the legislator, when determining the powers of particular State authorities, has not limited the power of authority of another branch of power below the minimum level.

In addition, it should be noted that the CT considers itself to be an authority empowered to make binding interpretations of the Constitution. In its opinion, for reasons of legal certainty, it is justified that the Constitution should be interpreted by the CT and not by any court or another authority deciding on a specific case. ${ }^{31}$ As we can see, the CT ascribes (tries to ascribe) its legal views to an important feature of legislative instruments: their binding character for other State authorities.

In this context, a partial law-making quality may be attributed to those statements where the CT decides on the choice of one of the various prima facie acceptable results of interpretation. One example of this relates to the understanding of the principle of the secrecy of voting in general elections and the decision as to whether it applies to the organization of the elections and the

27 Grzegorz Wierczyński, 'Uzasadnienie aktu stanowienia prawa jako źródło legitymizacji norm w nim ustanowionych' in Małgorzata Masternak-Kubiak et al. (eds.), Prawowitość wtadzy państwowej, (Beta-Druk 2014) 165,171.

28 Krzysztof Wojtyczek, Sadownictwo konstytucyjne w Polsce. Wybrane zagadnienia (Biuro Trybunału Konstytucyjnego 2013) 244.

29 This is particularly evident in the understanding of the rule of law.

$30 \mathrm{~K} \mathrm{6/94,} \mathrm{of} 21$ November 1994.

31 P 25/12, of 13 November 2013. 
authorities holding them or to the voters as well. The constitutional regulation is limited to stating that elections must be held by secret ballot. In one of its judgements, the CT held that 'for a voter, secrecy of the ballot is a privilege that $\mathrm{s} / \mathrm{he}$ can take advantage of, though without an obligation to do so. ${ }^{32}$ Regardless of our assessment of this standpoint, the creative element is clear here; it is not only a result of an interpretation made by means of the usual methods.

As far as the sub-constitutional level is concerned, it follows from Article 190(3) of the Constitution that the basic effect of the CT's finding that a normative act (or part of it) is incompatible with the Constitution (or another act of a higher rank in the legal system) is that legal act (part) losing its binding force. This is an obvious reference to the concept of the CT as a negative legislator.

However, an observation of the practice leads to the conclusion that the 'deletion' of norms by the CT may also produce other law-making results; namely, changing the content of other binding legal norms. Such a situation occurs in particular when the CT issues a partial judgement, which causes the scope of the application of other provisions to broaden or narrow. For example, in one of its judgements, the CT pronounced the ban on ritual slaughter unconstitutional. ${ }^{33}$ The statutory provision contested in that case stated that 'a vertebrate animal may be killed in a slaughterhouse only after it has been made unconscious by persons with appropriate qualifications.' The CT considered it unconstitutional, but only 'insofar as it does not allow animals to be slaughtered in slaughterhouses in accordance with specific methods required by religious rites.' Once this judgement entered into force, the law changed in such a way that the ritual slaughter of animals became lawful and the provision started to apply in a significantly modified form without any direct change in its wording.

The law-making influence of the CT's judgements on the sub-constitutional level results mainly from the so-called complex techniques of formulating the operative part of a judgement on unconstitutionality. In the Polish practice, not only partial judgements, but also interpretive and applicative judgements can be identified. ${ }^{34}$ Without delving into details, we should note that there is no legal basis - either in the Constitution or in statutory law - for issuing such judgements. The CT issues them, attempting in general to directly restore the state of compliance of the legal system with the Constitution; that is, without the need for the legislature to take action. The mere acceptance of their admissibility can be seen as an element of judicial law-making.

The law-making aspect of the Polish CT's judgements is also visible when it sets a different date for the loss of the binding force of unconstitutional normative acts than the date when the judgement was promulgated. The CT may postpone the 'entry into force of its judgement' by eighteen months with respect to statutes, and by twelve months with respect to other normative acts. ${ }^{35}$ The Constitution

$32 \mathrm{~K} 9 / 11$, of 20 July 2011.

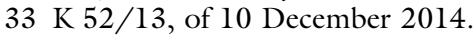

34 For more on the typology of CT judgments, see Monika Florczak-Wątor, Orzeczenia Trybunatu Konstytucyjnego $i$ ich skutki prawne (Ars Boni et Aequi 2006) 89 et seq.

35 Article 190(3) of the Constitution. 


\section{Law-making of the Polish Constitutional Tribunal}

does not specify the situations when the CT should exercise this power. ${ }^{36}$ Simi- $^{-}$ larly, it does not provide any guidance on how the length of the 'deferral' period should be determined. This means that the CT enjoys relative freedom in this regard.

We should add that certain 'indirect' powers of the Polish CT to influence the binding law result from the legislation. The CT notifies the Sejm and the Senate (both chambers of the Polish parliament), as well as other authorities with legislative power, of the existence of infringements and gaps in the law. ${ }^{37}$ This does not give the CT the right to legislative initiative; however, it may indicate the content of future legal provisions to the parliament.

\section{Evolution of the Constitutional Tribunal's case law in the area of law-making}

For more than the 30 years of the existence of the Polish CT, there have been farreaching changes in its judicial activism, which has also influenced the scope of its 'positive' influence on the existing legal order. In general, we can distinguish four periods. The first one covers the years from 1986 to 1989, when the adjudicating practice was taking shape. At that time, the CT focused on the issue of the relationship between statutes and government legislation. ${ }^{38}$ The second period lasted from 1990 to 1997, when, as a result of a political transformation, the CT was forced to concretize 'new' constitutional principles, which was reflected primarily in a very creative (extensive) interpretation (concretization) of the rule of law. One of the judgements summarizes the entire line of CT case law in this respect as follows:

One of the most important findings has been the assumption that the democratic rule-of-law clause is a kind of collective expression of a series of rules and principles that, although not explicitly mentioned in the written text of the constitution, result immanently from the axiology and essence of the democratic rule of law. [...] They concerned both substantive law (the existence of certain rights of an individual, such as the right to life, to privacy and, above all, to a fair trial, was considered a necessary element of the democratic rule of law) and the so-called principles of decent legislation (e.g. the prohibition of retroactivity of laws, the obligation to maintain 'appropriate' vacatio legis, the obligation to respect justly acquired rights). The general foundation was the recognition that the democratic rule of law requires respect for the principle of citizens' trust in the state and the laws it enacts. The latter requirement (referring to the construction of administrative law, and in

36 The Constitution only indicates that one of the cases is judgments that involve financial outlays not provided for in the Budget Act.

37 Article 35(1) of the Act on the CT's Organization.

38 Leszek. Garlicki et al., 'From scientific editors' in Leszek Garlicki et al. (eds.), $\mathrm{Na}$ straży państwa prawa. Trzydzieści lat orzecznictwa Trybunatu Konstytucyjnego (Wolters Kluwers 2016) 17, 18. 
particular to the German concept of Vertrauensschutz), combined with the principle of proportionality (prohibition of excessive interference), laid the general foundations for determining the shape and effects of the clause of the democratic rule of law. ${ }^{39}$

This quote does not indicate all the 'rules and principles,' which the CT formulated during that period on the basis of the democratic rule-of-law principle.

The subsequent period, which covers the years from 1997 to 2015, was characterized by a lesser degree of judicial activism. In this period, the CT supplemented its interpretations of some of the principles mentioned above by formulating general conditions that allowed for departures from them. In its case law, the CT formulated, for example, a test to verify the admissibility of departing from the principle of the protection of acquired rights in a specific situation. The test requires answering the following four questions: '(1) Are the introduced limitations based on other constitutional norms, principles or values? (2) Is it impossible to implement a given constitutional norm, principle or value without infringing on acquired rights? (3) Can the constitutional values, for the implementation of which the legislator limits the acquired rights, in a given specific situation, be given priority over the values underlying the principle of the protection of acquired rights? (4) Has the legislator undertaken the necessary steps aimed at ensuring conditions for the individual to adapt to the new regulation? ${ }^{40}$ This example shows an element that is typical of the process of creating judicial law; namely, the reliance on previous judgements in formulating assessments while introducing certain additions (further concretization).

At the level of statutes, the CT faced the problem of clarifying the effects of its judgements, with particular emphasis on the consequences of different types of judgements with 'complex operative parts.'

The last stage of the CT's activity started at the beginning of the constitutional crisis in the autumn of 2015. Initially, it was necessary to resolve the question of the scope of the legislator's freedom to regulate the position of the CT itself. Then, from December 2016, as a result of significant changes in the composition of the CT, its activism acquired a different character.

\section{Selected examples of the Constitutional Tribunal's law-making activity}

To illustrate the manifestations of the norm-forming activism of the Polish CT, it is worth presenting examples of specific judgements that not only resulted in a derogation of the binding regulations, but had a creative (positive) influence on the binding laws. Such an influence varies depending on the subject matter and on the basis of the review carried out by the CT, as well as the type of decision taken by

39 K 26/97, of 25 November 1997.

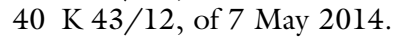




\section{6}

the CT. Undoubtedly, the most frequent form of the 'creative' reading of norms expressed by the legislator is the CT's operative interpretation of general constitutional principles, especially those relating to the legal status of an individual.

At this point, it is worth mentioning the judgements, which, in the contents of this formula and especially in the component principle of the citizen's trust in the state and the law, 'found' further rights that were not expressed in the text of the Constitution. The first is an individual's right to fair proceedings before public authorities. According to the CT, the rule of law enshrined in Article 2 of the Constitution implies 'a general requirement that all proceedings before public authorities conducted to resolve individual cases must comply with the standards of procedural justice. ${ }^{41}$ Another right decoded by the CT from the substance of general principles expressed in Article 2 of the Constitution is the right to good administration. In this case, the CT's argumentation was additionally based on an EU-compliant and international law-friendly interpretation of provisions of the Polish Constitution. ${ }^{42}$ In the opinion of the CT, the consequence of Article 2 of the Constitution is in 'granting to an individual (to everyone) the constitutional "right to good administration," understood as a bundle of procedural rights making administrative proceedings similar to court proceedings in which the parties enjoy considerable guarantees. ${ }^{43}$ This group of examples undoubtedly includes the interpretation of the Constitution's provisions adopted by the Polish CT, which allows for 'finding' in them the legal basis for Poland's functioning in the EU and for resolving conflicts between national law and EU law, despite the fact that at the time of the adoption of the Constitution, Poland was outside the structures of this international organization. ${ }^{44}$

This form of activism, which is manifested in the case of constitutional regulations, is of course also possible in relation to regulations contained in lower-ranking legal acts. As already mentioned, the possibility of the CT using so-called interpretive and partial judgements is also important in this context.

It should be emphasized that the effect of a dynamic interpretation of constitutional provisions may also be the 'radiation' of the Constitution to matters where, formally, the basis for a review and/or the subject of a review are the norms laid down in lower ranking legal acts. The consequence of the directive of the interpretation of these legal acts in accordance with the Constitution should be respect for the adopted and consolidated interpretation of its provisions. Such value can be attributed, for example, to the CT's findings concerning the constitutional conditions for enacting sub-statutory legal acts (regulations), in particular, the requirement of formulating correct guidelines that are consistent with the constitutional directive in the authorization contained in the statute. ${ }^{45}$ Taking account of this kind of influence, which refers

41 SK $3 / 11$, of 6 December 2011.

42 K 24/02, of 18 February 2003.

43 SK 54/05, of 18 December 2007.

44 K 18/04, of 11 May 2005; P 1/05, of 24 April 2005.

$45 \mathrm{~K} 12 / 99$, of 26 October 1999. 
to the axiology and philosophy of constitutional norms, is particularly important in matters within the sphere of the freedoms and rights of the individual. Therefore, examples of the latest judgements of the current Polish CT, in which this aspect of interpretation and then an assessment of the reviewed norms is clearly neglected, must be a cause for concern. ${ }^{46}$

\section{How the Constitutional Tribunal formulates decisions of a law- making nature}

From the point of view of the structure of the CT's judgements, we can say that elements of law-making at the constitutional level are usually visible in the statements of reasons. Only exceptionally does the CT formulate the infringed constitutional norm in the operative part of a judgement. The CT expresses it in a complex way by indicating that a specific legal regulation is inconsistent with the Constitution (e.g. with Article 2), because it violates a certain 'directive' that the CT considers to be an element of the rule of law. For instance, in one of its judgements, the CT stated that a statutory provision was inconsistent with Article 2 of the Constitution because it violated 'the requirement of definiteness of legal provisions resulting from that provision. ${ }^{47}$ It is clear from the above that the principle set out in the operative part of the judgement must be regarded as an element of the rule of law.

Under statutory law, the statement of reasons is not an integral part of a judgement. ${ }^{48}$ As far as its 'normative value' is concerned, there is a widespread view in Poland that the statement of reasons expresses the grounds and arguments, which led the adjudicating panel to reach a specific decision. Therefore, it does not have the same binding force as the operative part. ${ }^{49}$ Only statements of reasons issued by the full bench have special status. Where the panel that decides on a particular case intends to depart from a legal opinion expressed in a judgement issued by the full bench, that case must also be referred to the full bench for examination. ${ }^{50}$ It is clear that the legal view of the full bench of the CT is binding on all 'smaller' adjudicating panels. Therefore, judgements of the full bench may be attributed a law-making quality, while the legal views expressed in them should also constitute a certain 'pattern' for subsequent CT decisions.

As for the actual impact of the interpretive findings of the CT, a significant problem results from the fact that in Poland, in the official versions of its

$46 \mathrm{Kp} \mathrm{l} / 17$, of 17 March 2017.

$47 \mathrm{~K} 24 / 00$, of 21 March 2001.

48 The necessary structural elements of the judgment are listed in Article 105(1) of the Act on the CT's Organization.

49 Zdzisław Czeszejko-Sochacki et al., Komentarz do ustawy o Trybunale Konstytucyjnym, (Wydawnictwo Sejmowe 1999) 211.

50 Where the panel which decides on a particular case intends to depart from a legal opinion expressed in a judgement issued by the full bench, that case must also be referred to the full bench for examination (Article 35(1)(1)(e) of the Act). 
judgements (published in electronic form in the collection Orzecznictwo Trybunatu Konstytucyjnego), the judicial theses are not distinguished. This sets the CT apart from other supreme judicial authorities (the SC and SAC), which do apply this practice. The judicial theses, which are one- or multi-sentence quotes from the statements of reasons, usually concern the abstract resolution of interpretive problems that are relevant for other cases as well. As in many other countries, citing the case law of the SC (or the SAC) by quoting the judicial thesis is an important element of pleadings, statements of reasons for court decisions, and views presented in legal journals or monographs. ${ }^{51}$ Thus, these judicial theses sometimes become more important than the wordings of the relevant provisions themselves.

In this context, the different practice followed by the CT may come as a surprise. This is all the more so given that the statements of reasons for its decisions are relatively long and it is often difficult to determine which views are important and relevant beyond the given case. On the other hand, it can also be argued that it is an expression of the desire to avoid the petrification of the Constitution's interpretation by treating, in practice, the judicial thesis in a dogmatic (mechanical) manner without taking into account the particularities of other situations. It should be noted, however, that many scholars have attempted to fill this gap. ${ }^{52}$ However, the emphasis on certain passages from the statements of reasons for CT judgements in the literature does not have such a practical impact as the judicial thesis 'authorized' by the CT itself would have.

\section{Legal scholarship on the Constitutional Tribunal's law-making activity}

Since its establishment, the activity of the CT has caused various disputes among legal scholars, not only in the context of the issues discussed here. ${ }^{53}$ Apart from the fundamental dilemmas concerning the democratic legitimacy of the CT and its judges to perform the very function of reviewing the constitutionality of statutes, these disputes are also connected to the problem of this authority's activism in the broad sense, including the issue of the normative influence of its case law. The arguments formulated by critics of this activity by the CT are rooted primarily in the concept of the CT as an exclusively 'negative law-maker,' whose powers should be limited to derogating defective provisions from the system of binding laws. In the positive law context, it has also been pointed out that there is no express constitutional normative basis for making the CT a 'creator' or even just a 'modifier' of binding

51 Grzegorz Orłowski, 'Kilka uwag o tezowaniu orzeczeń' (2016) l Monitor Prawa Pracy (10 August 2019), https://czasopisma.beck.pl/monitor-prawa-pracy/aktua lnosc/kilka-uwag-o-tezowaniu-orzeczen/.

52 See Marek Zubik (ed.), Konstytucja III RP w tezach orzeczniczych Trybunatu Konstytucyjnego $i$ innych sadów (CH Beck. 2008).

53 See Wojtyczek (n 28), 265 et seq. 
legal norms. Additional confirmation of this is sometimes perceived in the fact that, in 1997, the Constitution-maker deprived the CT of the function of determining the universally binding interpretation of statutes.

On the other hand, those who approve of the CT's creative role in the norm-forming sphere emphasize the derivative and purely applicative nature of the CT's influence in the field of law-making. This influence is, after all, a consequence of the decisions taken by the CT - decisions that always concern the problem of the (in)compatibility of the reviewed legal norms. Consequently, it is stressed that the effects of CT judgements escape the simple classification of those operating ex tunc or ex nunc. As has already been explained above, the problem of the Polish CT's activity in the norm-forming sphere requires different approaches depending on the hierarchical level of the sources of law that this activity may concern. The CT's activism in relation to constitutional norms, which only constitute the basis for the review it conducts, is qualitatively different from the forms it assumes in relation to hierarchically lower legal acts, which are both the subject of and the basis for the review of laws. In the first situation, the 'creative' role of the CT is justified by the need for an operative determination of the meaning of many general terms used in the Constitution. In the latter case, the activity of the CT is significantly enriched by the fact that the CT makes decisions of a quasi-validative nature. Such a qualification can be attributed to those CT judgements, which result not only in derogating the provisions of law, but also (or only) in modifying the scope of application of the legal norms decoded from provisions reviewed in terms of their constitutionality and legality. Disputes among legal scholars, subsequently reflected in judicial decisions, result from the very fact that the CT uses such a tool. The doubts that accompany interpretive judgements or partial judgements are thus transferred to the question of the effects that they may produce in the system of binding laws.

\section{Courts' reactions to manifestations of the law-making activity of the Constitutional Tribunal: Selected problems}

In general, it can be said that the courts did not question the quasi-legislative activity of the CT at the level of constitutional norms. In principle, acceptance was expressed in an indirect form, by means of quoting legal views contained in the statements of reasons of CT judgements that were related to the understanding of some provisions of the Constitution. Since court decisions are usually based on the provisions of statutes, references to the case law of the CT were infrequent and mainly concerned issues affecting the resolution of doubts about the interpretation of statutory provisions.

There was an exception: the question of the courts' competence to review the constitutionality of statutes. It is not explicitly regulated for in the Constitution. The CT has consistently expressed the position that: '[D]irect application of the Constitution cannot be understood as authorizing courts to refuse to apply statutory provisions in force, instead of referring an appropriate question of law to the 
CT. ${ }^{54}$ The SC (in some judgements) presented a different position. ${ }^{55}$ Without discussing the substance of the dispute from the point of view of the legitimacy of one view or another, it should be noted that the SC (and in some instances, other courts) mainly questioned the fact that the CT tried to limit their powers, but a subsidiary role was also played by the fact that the position of the CT was alleged to have an essentially law-making quality.

At the statutory level, the evaluation is slightly more complicated. From 1990 to 1997 , the CT was authorized to make a generally binding interpretation of statutes. CT resolutions issued on this basis often had a law-making quality in the sense that the interpretation adopted by the CT clearly went beyond a linguistic interpretation and was aimed at achieving a state of law that would correspond (to the greatest extent possible) to constitutional standards. The SC questioned the binding force of such resolutions, chiefly by invoking the principle of judges only being subject to statutes. For obvious reasons, after the Constitution of 1997 abolished the universally applicable interpretation of laws, the controversy came to an end.

Since the 1997 Constitution entered into force, the most important example of a dispute between courts and the CT has been the conflict over the admissibility and legal effects of interpretive judgements. The CT stated in these judgements that a statutory regulation was consistent with the Constitution provided that a certain interpretation was adopted or that it indicated that a certain understanding (interpretation) of a statute was inconsistent with the Constitution. The essence of the objections the courts had about interpretive judgements can be reduced to the statement that the CT had granted itself the power to make such decisions, and thus had itself established a competence norm, acting in excess of its powers. However, the 'axis' of the dispute was actually of a different nature. The point was that the SC was of the opinion that interpretive judgements constituted an unauthorized interference with the interpretive independence of courts to the extent of interpreting statutes (and other sub-constitutional legal acts), while the Constitution did not provide for the CT's power to review judicial decisions, including with regard to how the provisions of law were interpreted in them.

However, what seems of most interest are two other issues, which clearly show that courts do treat CT judgements as a kind of source of law, capable of being the basis for resolving a specific case. The first issue is that of the consequences of the judgements in which the CT finds a certain statutory regulation unconstitutional, but only to the extent that it omits certain groups of similar facts. This particular judicial technique of the Polish CT is based on a distinction between a so-called proper (absolute) legislative omission and a so-called relative (partial) legislative omission. The former involves the lack of regulation of a specific area of social relations, and the CT has no jurisdiction to examine such cases. In the second case, the existing regulation omits specific groups of facts, although in the

$54 \mathrm{~K} 36 / 01$, of 28 November 2001.

55 Leszek Garlicki, ‘Sąd Najwyższy' in Wiesław Skrzydło (ed.), Sady i Trybunały w Konstytucji $i$ w praktyce (Wydawnictwo Sejmowe 2005) 15, 22. 
light of constitutional principles (in particular, the principle of equality before the law), they should be covered by it. In cases where a relative omission is found, the CT makes a decision on the merits and issues of a specific partial judgement. In the judgement, it states unconstitutionality, but only to the extent of the omission, which does not result in the derogation of the challenged provision.

From the point of view of the subject matter of this study, it is important to state that courts treat these kinds of judgements concerning relative omissions as the basis for determining changes in the state of law and for decisions where the opinion is expressed that a CT judgement is an independent basis for extending the application of a given regulation to also cover the 'omitted' situations without changing the wording of the applicable provisions. ${ }^{56}$

\section{Effects of the Constitutional Tribunal's law-making activity and prospects for the future: a summary}

In light of the considerations presented in this chapter, the basic hypothesis seems fairly obvious that the CT's activity in the field of the 'creation' of constitutional norms mainly resulted in determining the substance of some constitutional principles with greater precision, thus facilitating the assessment of the constitutionality of statutes, but also affecting the interpretation and application of sub-constitutional legal acts. The consequence of this is a significant reduction in uncertainty as to the substance of these principles.

The principles that the CT formulated in its case law as concretizations of constitutional regulations did not also provoke any major objections because, to a considerable degree, they were an adoption of the case law of other constitutional courts (especially the German Federal Constitutional Court). Whenever the Polish CT's activism in the area of formulating constitutional principles and norms not expressed in the text of the Constitution was criticized, it was for methodological reasons (arbitrariness manifested in the lack of appropriate justification and acting in excess of the powers granted to it by the Constitution).$^{57}$

Practical problems were much more frequent in situations where the CT created (concretized) norms at the statutory level. Particularly in cases involving interpretive judgements, this was met with a certain amount of 'resistance' from courts, especially the SC.

Shaped mainly in the period from 1990 to 1997, the practice, which actually permits the law-making activity of the CT, to a relatively broad extent, will probably continue in the future. However, in connection to the constitutional crisis and the far-reaching changes in the CT's composition, there is a justified concern that it will be used for different purposes and in a different way than before. Currently, out of the members of the Polish constitutional court, as many as two-

56 Monika Florczak-Wątor \& Piotr Czarny (eds.), Oddziatywanie sadu konstytucyjnego na porzadek prawny Austrii, Niemiec i Polski (Księgarnia Akademicka 2019).

57 B Banaszak, Prawo konstytucyjne, (C.H. Beck 2012), 87. 
thirds of them have been elected by the Sejm from among candidates put forwards by one political party. ${ }^{58}$

Without delving into details, it can only be pointed out that some CT judgements and the interpretations or concretizations of constitutional norms they contain may be treated as legitimizing legislative solutions. Such legitimacy is highly doubtful from the point of view of the constitutional axiology. The way the technique of partial judgements is used began to show symptoms of a preventive influence on the direction of case law. ${ }^{59}$ In this context, there is a concern that the case law of the CT resulting from its previous practice will serve as an additional argument for the parliamentary majority to justify the 'validity' of the adopted statutes and limit the possibility of judicial reviews of the activities of the executive power. There may also be a specific 'reinterpretation' of the Constitution.

58 Not insignificantly, there are also reservations regarding the correctness of the election of CT judges in November 2015.

59 Helsinki Foundation for Human Rights, “"Pracuje tak, jak powinien?” TK w 2017 r.' (9 August 2019), https://www.hfhr.pl/wp-content/uploads/2018/03/HFPC-Pra cuje-tak-jak-powinien-raport-TK-2017.pdf. 